\title{
Jagters vs Boere: 'n Soeke na die oorsprong van godsdiens
}

\begin{abstract}
Author:
Jaco Beyers ${ }^{1}$

Affiliation:

${ }^{1}$ Department of Science of

Religion and Missiology,

University of Pretoria,

South Africa

Correspondence to:

Jaco Beyers

Email:

Jaco.beyers@up.ac.za

Postal address:

Private bag X20, Hatfield,

Pretoria 0028, South Africa

Dates:

Received: 01 Aug. 2011

Accepted: 21 Sept. 2011

Published: 20 Feb. 2012

How to cite this article: Beyers, J., 2012, 'Jagters vs Boere: 'n Soeke na die oorsprong van godsdiens', Verbum et Ecclesia 33(1), Art. \#580, 4 pages. http://dx.doi. org/10.4102/ve.v33i1.580
\end{abstract}

The question to the origin of religion is as old as the concept of religion itself. To understand religion, it helps to understand the categories of definitions for religion. There are several theories as to the evolutionary development of religion. Examples from Turkey as well as South Africa are used to illustrate that one model of explanation cannot be applied to all. This article wants to stress the importance of context when explaining the origin of religion. Each and every occurrence of religion has its own contextual explanation. What is however important is to recognise the universal human ability to recognise, accept and transfer religious concepts. This principle is illustrated by making use of the model of cognition in combination with other models.

\section{Inleiding}

Die vraag na die oorsprong van godsdiens is ' $n$ baie bekende onbeantwoorde vraag. Daar is oor die eeue talle voorbeelde van pogings om die vraag te beantwoord. Sommige antwoorde is meer waarskynlik as ander. Die antwoord op die vraag na die oorsprong van godsdiens hang af van wie die vraag vra. So bestaan daar antwoorde uit die hoek van sosioloë, psigoloë, teoloë, argeoloë en selfs bioloë. Dit het waarskynlik meer waarde om die groot aantal definisies in kategorieë saam te groepeer en die kategorieë te analiseer. Vergelyk in hierdie verband Cox se indeling van kategorieë (Cox 1992:3-4). Cox (1992:4) identifiseer die volgende vyf kategorieë van definisies:

- Teologiese

- Etiese

- Filosofiese

- Psigologiese

- Sosiologiese.

Die biologiese benadering om ' $n$ definisie van godsdiens te gee, kan egter as sesde kategorie by Cox se lys gevoeg word. Onder die biologiese definisies sorteer die benadering van Hamer (2004) wat voorstel dat daar 'n God-geen in die menslike DNA bestaan wat maak dat die mens biologies gedetermineer is om godsdienstig te wees. Die God-geen verklaar waarom sommiges meer as ander tot godsdienstigheid geneig sal wees. Hamer (2004:161) wys daarop dat die godsdienstigheid in die menslike geheue vasgevang en oorgedra kan word. Hierdie oordraagbare kultuur word deur Dawkins 'meme' genoem (Hamer 2004:161). Soos gene biologiese data oordra, dra meme kulturele data van een generasie na 'n ander oor. In hierdie opsig speel gene en die invloed van die omgewing (kulturele kennis) 'n rol by die aanvaarding van godsdienstige oortuigings by individue (Hamer 2004:175). Die mens se behoefte aan sekerheid of vrede wat in bepaalde godsdienstige oortuigings gevind word, begin by die brein se vermoë om sulke oortuigings te ontvang en te verwerk, dit wil sê, in die biologiese samestelling van die brein (Hamer 2004:176).

Hierby sluit Boyer (2001) aan met sy kognitiewe benadering tot die verklaring van godsdiens. Die menslike brein is van so aard dat dit ontvanklik vir godsdienstige konsepte is. Dit maak die mens met 'n brein nie godsdienstig nie, maar skep die moontlikheid tot godsdiens.

Die definisie en verklaring van godsdiens, sê Sundermeier (1999:26), sê eintlik meer oor die een wat antwoord as wat die antwoord oor die saak iets sê.

'n Ondersoek na die oorsprong van die woord 'godsdiens' kan dui op die onderliggende denke oor die saak waarna die woord verwys. Die woord 'religion' kom van die Latyn religio. Die wortel van die woord het 'n tweërlei oorsprong: re-ligare, 'om te verbind' soos deur Augustinus gebruik is (Urban 2003:88) en religere, 'om nougeset te let' soos deur Cicero gebruik is (Urban 2003:88). Die twee woorde val waarskynlik binne twee verskillende semantiese velde (vergelyk die model van semantiese velde van Louw en Nida 1989:vi-xx). Religare val waarskynlik binne die domein van assosiasie met sub-domein verbintenis (Louw \& Nida 1989:446) en religere binne die domein van verhoudings, met sub-domein afhanklikheid (Louw \& Nida 1989:777). 'Religion' - in Afrikaans 
vertaal as 'godsdiens' - wil dus verwys na die passiewe verbondenheid van die mens met gode asook die aktiewe verpligting van die mens teenoor die gode (Urban 2003:88). Hierdie betekenis lê opgesluit in die woord 'godsdiens'; diens aan gode.

Die bedoeling is egter nie om godsdiens te reduseer tot die fokus op gode alleen nie, soos wat inderdaad sommige definisies dit stel nie. Vergelyk in dié verband Tylor (1924:424) se definisie van godsdiens as die erkenning en aanbidding van bonatuurlike geeste en wesens; 'Spiritual Beings'. Hierdie artikel wil juis aandui dat een benadering en verklaring tot die oorsprong en ontwikkeling van godsdiens onbevredigende resultate oplewer.

\section{Die oorsprong van godsdiens: Turkye}

In die Junie 2011 uitgawe van National Geographic verskyn 'n verslag deur Charles Mann waarin hy 'n antwoord bied op die vraag waar godsdiens vandaan kom.

Vir die afgelope 100 jaar is die algemene teorie onder sosioloë en argeoloë dat die mens (homo sapiens) sowat 200000 jaar gelede op die toneel verskyn het. Vergelyk Mann (2011:49) se verwysing na Childe se teorie wat hieronder beskryf word. Urban (2003:101) meen homo sapiens tree eers na vore rondom 40000 jaar gelede en dat godsdienstige voorstellings en ontwikkeling sedert hierdie tyd geïdentifiseer kan word. Die eerste mens het 'n nomadiese bestaan as jagters en reisende kossoekers gevoer. Volgens Childe se teorie (vgl. Mann 2011:49) het daar tydens die neolitiese periode (ongeveer vanaf 10000 v.C.) 'n radikale verandering gekom wanneer die mens met gevestigde landboupraktyke begin. Hierdie skuif het gemaak dat mense permanent in klein gemeenskappe gevestig het. Hierdie stabiele bestaan het gelei tot die uitbreiding van kuns en kultuur. So byvoorbeeld is landbougereedskap en kleipotte begin vervaardig. Hierdie vroeë vorm van industrialisasie het die produksie van kos verhoog en die mortaliteit van die mens verlaag. Meer mense kon gevoed en versorg word. Dorpies het begin groei en ontwikkel in klein gemeenskappies.

Deel van die ontwikkeling was die evolusionêre groei in kuns en godsdienstige denke. Hierdie fase van ontwikkeling van die mens is egter beperk tot wat argeoloë die 'Vrugbare Halfmaan' noem. Die gebied beslaan Israel, strek noordwaarts deur die suide van Turkye en strek weer suidwaarts tot in vandag se Irak. Die gebied sluit ook in die gebied bekend as Sumer, die gebied tussen die Tigris- en Eufraatrivier. Dit word tradisioneel aanvaar dat Sumer vanaf 4000 v.C. die bakermat van beskawing was.

Childe se teorie word egter bevraagteken wanneer argeoloë vanaf die 1950's met opgrawings in Libanon, Sirië en Jordanië aantoon dat daar reeds suksesvolle gemeenskappe sedert 13000 v.C. bestaan het. Hierdie gemeenskappe het as die Natufiaanse dorpies bekend geword (Mann 2011:56).

\section{Landbou- en Jagtergemeenskappe}

Die debat word op die spits gedryf wanneer die tradisionele teorie van Childe, dat landbouaktiwiteite gelei het tot beskawing en die ontstaan van dorpies, bevraagteken word. Die Natufiaanse gemeenskappe was gevestigde dorpies van mense wat 'n bestaan uit jag en kos soek gemaak het en nie uit landbou nie. Argeologie bewys dus dat vestiging eers plaasgevind het en dat landbou eers later ontstaan het. Dit verskil van die heersende teorie dat landbouaktiwiteite tot dorpstigting gelei het.

Die ontstaan van georganiseerde godsdienspraktyke hou direk verband met hierdie ontwikkeling van menslike habitasie. Tradisioneel is gereken dat godsdiens ontwikkel nadat jagters en kossoekers in gevestigde gemeenskappe permanente woning kry. Dan eers is daar begin om permanente strukture op te rig waarin godsdiensaktiwiteite beoefen kon word.

'n Argeologiese fonds by'n dorpie in die suide van Turkye wys egter die teendeel. Mann (2011:40) berig hoe die argeoloog, Klaus Schmidt, by Göbekli Tepe in Turkye, permanente strukture, onder meer vermoedelik 'n tempelkompleks, ontgin wat uit 11000 v.C. dateer. Die aard van die strukture laat 'n sterk vermoede dat godsdienstige aktiwiteite daar plaasgevind het. Tot dusver is daar egter geen aanduiding van permanente inwoning deur argeologiese opgrawings gevind nie. Sirkelagtige strukture bestaande uit groot pilaarstene waarop graverings van mense en diere voorkom, skep die indruk dat die plek vir godsdiensaktiwiteite benut is (Mann 2011:48, 57).

Dit was vir lank die aanvaarde teorie onder antropoloë dat godsdiens uit die permanente vestiging van eens jagters- en kossoekergemeenskappe voortgevloei het. Sulke gemeenskappe het die luukse van permanensie gehad in terme van woonplek en landbou. Die gemeenskap is saamgebind deur 'n gemeenskaplike doel en kollektiewe verstaan van die kosmos. Daarmee saam kon sosiale praktyke gestandaardiseer en gevul word met religieuse betekenis, byvoorbeeld die skep van kuns en kultuur, geskiedenisoorvertelling, dooies wat begrawe word, die viering van seisoenwisseling en ander sikliese rituele. Sosiale bande en hiërargie is ook deur godsdienstige beginsels bepaal: die leiers in die groep se sosiale posisie is deur die magte en gode gelegitimeer.

Die argeologiese fonds by Göbekli Tepe bevraagteken die bestaande tradisionele teorie van Childe (Mann 2011:49). Die fonds van 'n reuse tempelkonstruksie by Göbekli Tepe wat deur 'n jagter- en kossoekergemeenskap opgerig is, is bewys dat georganiseerde godsdiens ontstaan het voor die totstandkoming van landbougemeenskappe en ander elemente van beskawing in plek was.

Mann (2011:57) wys daarop hoe antropoloë wil aandui dat die ontstaan van godsdiens te danke is aan die kopskuif 
by die primitiewe mens. Die mens het wegbeweeg van 'n paradigma waar die mens as deel van die natuur beskou is, na 'n paradigma waar die mens as heerser oor die natuur beskou is. Hierdie skuif om nie meer te soek en te jag vir kos nie, maar gevestig op een plek te woon en kos te verbou, het die mens grense laat skep. Die woonplek (hutte en vuurherd) het die teken van lewe en beskawing geword. Alles daarbuite was die plek van die natuur (onbeskaafde wêreld). Die mens het behoefte aan beskerming van die natuurwêreld benodig. Om hierdie rede skep die mens simbole van gode (wesens wat soos mense en diere lyk maar sterker as gewone mense is) om hulle te beskerm. Die gode woon in 'n ander wêreld as die fisiese wêreld wat die mens sien en ervaar.

Afbeeldings van diere (soos dié op die pilare by Göbekli Tepe) is as bewaarders van die poorte na die ander wêreld waar die gode woon, gesien (Mann 2011:57). Argeoloë spekuleer dat die tempelkompleks by Göbekli Tepe waarskynlik deur jagters- en kossoekergemeenskappe van die omliggende omgewing as bymekaarkomplek gebruik is (Mann 2011:57). Jagters- en kos-soekergemeenskappe is vir oorlewing afhanklik van die migrasiepatrone van diere wat gejag word asook seisoenale groei van eetbare plante. Bymekaarkomste van reisende jagters en kossoekers was waarskynlik vir sosiale sowel as religieuse doeleindes. By sommige argeologiese opgrawings in die omliggende gebiede rondom Göbekli Tepe is soortgelyke simbole van diere op klippe gevind. Dit wil dus voorkom of die godsdiens wat by Göbekli Tepe beoefen is wye aanhang geniet het.

Daar bestaan dus vele teorieë oor die ontstaan van georganiseerde godsdiens. Eerstens is daar Childe se tradisionele teorie dat landboupraktyke die oorsprong van godsdiens en beskawing was. Ander (argeoloë en antropoloë) meen weer, na aanleiding van Göbekli Tepe en die Natufiaanse dorpies, dat godsdiens en kuns tot beskawing gelei het. Aan die een kant is die teorie dat landbou tot die ontstaan van georganiseerde godsdiens lei en aan die ander kant staan die teorie dat georganiseerde godsdiens tot die ontstaan van landbouaktiwiteite kon lei. Die gevolgtrekking waartoe Mann (2011:58) kom, is dat daar nie 'n keuse uitgeoefen hoef te word ter wille van een teorie nie. Waarskynlik het elke gemeenskap hulle eie unieke rede vir die ontstaan van beskawing. Waaroor antropoloë saamstem is dat die oorgang van bestaanswyse, van nomadiese jagteren kossoekgemeenskap tot gevestigde landbougemeenskap, die vonk was wat aanleiding gegee het tot die ontwikkeling en groei van godsdiens.

\section{Die oorsprong van godsdiens: 'n Afrika-perspektief}

Dieselfde vrae oor die oorsprong en ontwikkeling van godsdiens wat na aanleiding van Göbekli Tepe gevra word, kan ook oor ' $n$ nuutgevinde argeologiese fonds in SuidAfrika gevra word. Sedert 2003 is daar 'n groeiende aantal strukture in Mpumalanga ontdek wat dui op die bestaan en aktiwiteite van ' $n$ antieke beskawing in die omgewing. Reuse klippilare wat in sirkelpatrone gerangskik is en waarskynlik een of ander religieuse betekenis het, is in die omgewing van Machadodorp en Waterval Boven ontdek. Verskeie ander klipkonstruksies wat wonings, krale of tempels kon wees is ook in die omgewing ontdek. Die merkwaardigste is dat dit wil blyk dat daar menslike aktiwiteite by van die ruïnes was tot so ver terug as 160000 jaar gelede, aldus Thellinger en Heine (2009:28, 31).

Thellinger en Heine maak daarop aanspraak dat hulle tekens van die bestaan van ' $n$ antieke stad groter as die huidige Johannesburg in die omgewing van Mpumalanga gevind het. Tekens van 'n netwerk van paaie en sirkelagtige kontruksies en terasse is net onder die grondoppervlak sigbaar. Die oorsprong van hierdie antieke beskawing lê waarskynlik in die grootskaalse migrasie van inheemse volke. Die reuse migrasie van volke van die noorde na suidelike Afrika, en veral Zimbabwe, kan dateer word vanaf die Christelike jaartelling 0, tot by 1200 n.C. (Thellinger \& Heine 2009:27). Die rotstekeninge van die Khoi, word beweer, is tot 2000 jaar oud. Thellinger en Heine glo dat op grond van die argeologiese fonds wat hulle gevind het, daar 'n veel ouer en veel groter antieke beskawing eens in suidelike Afrika gewoon het; 'n beskawing wat deeglike kennis van steenwerk en skryfkuns gehad het (Thellinger \& Heine 2009:29), 'n beskawing wat blyk kontak met die antieke Sumeriese en Egiptiese beskawing gehad het (Thellinger \& Heine 2009:34).

Matole Motshekga (ongepubliseerde voordrag by ASRSAkonferensie, 20 Julie 2011, Bloemfontein) propageer dat daar ' $n$ antieke godsdiens in Afrika bestaan het waaruit alle ander wêreldgodsdienste gegroei het. Gegrond op ooglopende ooreenstemmende kenmerke dui Motshekga ietwat onoortuigend aan dat hierdie antieke Afrika-godsdiens noue bande met die antieke Egiptiese godsdiens het. Tekens van 'n antieke beskawing wat in Suid-Afrika gevind word, soos deur Thellinger en Heine geïdentifiseer is, ondersteun maar bevestig nie onomwonde Motshekga se teorie nie.

Die vraag na die godsdiens van hierdie antieke beskawing blyk' $n$ verband met die vraag na die oorsprong van godsdiens by Göbekli Tepe te hê. Uit die steenpilare in Mpumalanga is dit duidelik dat die oprigters daarvan deeglike kennis van astronomie gehad het. Die sterrebeeld, Orion se gordel, speel 'n belangrike rol in die konfigurasie van die stene by een spesifieke plek in Mpumalanga, Adam's Calender genoem deur Thiellinger en Heine (2009:30). Die posisie van die reuse rotsblokke weerspieël 'n konfigurasie met Orion se gordel soos die stand van die sterre 160000 jaar gelede was.

As Adam's Calender ' $n$ aanduiding van georganiseerde godsdiensaktiwiteite is, en werklik dateer uit 160000 jaar gelede, dan is die vraag weereens wanneer godsdiens ontstaan het; voor of nadat landbouaktiwiteite tot stand gekom het? Die groot denkfout wat 'n mens sou maak as 'n mens die situasie by Göbekli Tepe en Mpumalanga onder oë neem, is dat geen godsdiens voor 'n sekere datum bestaan het nie. Selfs by jagters- en kossoekergemeenskappe was daar ' $n$ bewussyn van die transendente. Georganiseerde en gestruktureerde godsdiensaktiwiteite kon weliswaar 
gegroei het uit 'n gevestigde landbougemeenskap, maar tog is daar tekens van godsdienselemente by die antieke mens teenwoordig.

Schmidt (1988:4) dui op aktiwiteite van godsdienstige betekenis by antieke gemeenskappe so oud soos 50000 tot 70000 jaar gelede. Neanderthal oorledenes is begrawe in spesifieke posisies en saam met gereedskap en kleifigure, aanduidings van 'n dieper betekenis en geestelike waarde wat aan lewe gekoppel is. Dit wil dus voorkom of daar vorme van godsdiens by die primitiewe jagters- en kossoekergemeenskappe te bespeur is. Eliade (1958:243) gee toe dat die godsdiens van die pre-landbougemeenskap meer daarop gefokus het om die krag van die goddelike horisontaal op die aarde te fokus. Later met die koms van landbouaktiwiteite het die fokus na die hemelruim verskuif en die sogenaamde Chtoniese godewêreld tot gevolg gehad (Eliade 1958:243).

Die gevolgtrekking is dus dat die groei en ontwikkeling van godsdiens nog 'n onopgeloste vraagstuk bly. Childe se teorie dat georganiseerde godsdiensaktiwiteite eers met die koms van landbouaktiwiteite gekom het, is dus deels waar. Dit mag dalk waar wees van die spesifieke gemeenskap wat by Göbekli Tepe geleef het, maar die model kan nie net so oorgedra word na 'n nuwe konteks, soos na die gemeenskap wat in Mpumalanga geleef het nie. Godsdiens bestaan dus langer as wat menslike kultuur bestaan.

\section{Kognisie}

Die uiteinde is om terug te val op die beginsel van homo religiosus (Schmidt 1988:7); die mens is inherent religieus. Boyer (2001:3) bied 'n meer genuanseerde verduideliking van hierdie beginsel vanuit die kognisie. Die verduideliking van godsdiens moet gesoek word in die wyse waarop die menslike verstand werk. Hoewel godsdiens verskillend op verskillende plekke lyk, is die wyse waarop die menslike verstand inligting ontvang en organiseer dieselfde (Boyer 2001:3). Die menslike verstand het so oor tyd evolusionêr verander dat dit ontvanklik is vir spesifieke godsdienstige konsepte (Boyer 2001:4). Dit beteken egter nie dat godsdienstigheid inherent in die menslike gene vasgevang is nie. Die menslike verstand het die kapasiteit om godsdienstige konsepte te verwerk, net soos die menslike verstand die kapasiteit het om musiek te erken en te waardeer al is die mens nie inherent musikaal nie. 'n Gesonde menslike brein waarborg dus nie dat ' $n$ mens godsdiens het nie, maar dit beteken dat ' $n$ mens wel godsdienstig kan wees (Boyer 2001:5).

Jensen (2009:131) beskuldig Boyer daarvan dat kognisie net nog 'n reduksionistiese manier is om die oorsprong van godsdiens aan die hand van een noemer te interpreteer.
Hoewel Jensen se kritiek geldig mag wees oor sosiologiese, psigologiese, argeologiese en selfs biologiese benaderings tot die verduideliking van die verskynsel godsdiens, stel Boyer nie' $n$ metode voor hoe om godsdiens te interpreteer nie, maar hoe om dit te verduidelik (Jensen 2009:131). Boyer gee slegs 'n verklaring waarom die mens godsdienstige verskynsels kan erken, handhaaf en oordra aan 'n volgende generasie. Kognisie gee nie 'n verklaring van die wese of oorsprong van godsdiens nie. Daarom dat kognisie as model juis bruikbaar is in die verstaan van godsdiens, aangesien dit in kombinasie met ander verklaringsmodelle sin maak.

Dit maak nie saak op watter plek die mens woon of bestaan nie; watter vorm van kultuur (nomadiese jagter of kossoeker of gevestigde landbouer) heers nie, hierdie mens het 'n behoefte en vermoë om godsdienstige konsepte te identifiseer, te aanvaar en oor te dra aan 'n volgende generasie.

Die uitdrukking van religieusiteit varieer volgens tyd en plek. Een verklaringsmodel kan nie net so op alle verskynsels van godsdienstigheid toegepas word nie. Elke konteks het 'n eie unieke verklaring vir die ontstaan van godsdienstigheid soos dit op daardie plek verskyn. Dat die mens vatbaar vir godsdiens is, is duidelik. Hoe daardie godsdiens lyk, verskil na gelang van die konteks en geskiedenis van elke omgewing.

\section{Erkenning Mededingende belange}

Die outeur verklaar dat hy geen finansiële of persoonlike verbintenis het met enige party wat hom nadelig kon beïnvloed in die skryf van hierdie artikel.

\section{Literatuurverwysings}

Boyer, P., 2001, Religion explained: The human instincts that fashion gods, spirits and ancestors, William Heinnemann, London.

Cox, J.L., 1992, Expressing the Sacred: An Introduction to the Phenomenology of Religion, University of Zimbabwe Publications, Harare.

Eliade, M., 1958, Patterns in Comparative Religion, Sheed \& Ward Inc., New York.

Hamer, D.H., 2004, The God gene: How faith is hardwired into our genes, Anchor Books, New York.

Jensen, J.S., 2009, 'Religion as the unintended product of brain functions in the "standard cognitive science of religion model": On Pascal Boyer, Religion explained (2001) and Ilkka Pyssiäinen, How religion works (2003)', in M. Stausberg (ed.), Contemporary theories of Religion: A critical companion, pp. 129-155, Routledge, New York.

Louw, J.P. \& Nida, E.A., 1989, Greek-English Lexicon of the New Testament based on Semantic Domains, United Bible Societies, Cape Town.

Mann, C.C., 2011, 'The Birth of Religion', in National Geographic, pp. 34-59, National Geographic Society, Washington DC.

Schmidt, R., 1988, Exploring Religion, 2nd edn., Wadsworth Publishing, Belmont.

Sundermeier, T., 1999, Was ist Religion? Religionswissenschaft im theologischen Kontext, Chr Kaiser/Gütersloher verlagshaus, Gütersloh.

Tylor, E.B., 1924, Primitive Culture: Researches into the Development of Mythology, Philosophy, Religion, Art and Custom, 7th edn., Brentano's Publishers, New York. http://dx.doi.org/10.1037/13484-000

Tellinger, M. \& Heine, J., 2009, Temples of the African gods, Zulu Planet Publishers, Waterval Boven.

Urban, O.H., 2003, 'Religion der Urgeschichte', in J. Figl (Hrsg.), Handbuch der Religionswissenschaft, pp. 88-103, Vandenhoeck \& Ruprecht, Göttingen. 